\title{
Two novel peptides derived from Sinonovacula constricta inhibit the proliferation and induce apoptosis of human prostate cancer cells
}

\author{
FANGFANG HUANG, GUOFANG DING, ZUISU YANG and FANGMIAO YU
}

\begin{abstract}
Department of Pharmacy, School of Food Science and Pharmacy, Zhejiang Provincial Key Engineering Technology Research Center of Marine Biomedical Products, Zhejiang Ocean University, Zhoushan, Zhejiang 316000, P.R. China
\end{abstract}

Received July 1, 2016; Accepted April 19, 2017

DOI: $10.3892 / \mathrm{mmr} .2017 .7418$

\begin{abstract}
In China, the incidence of prostate cancer has been increasing. Toxicity, drug resistance and limited transient benefits in patients are the main problems associated with standard chemotherapeutic regimens, and new drugs are therefore required to treat prostate cancer. SCH-P9 and SCH-P10 proteins were obtained from Sinonovacula constricta hydrolysates. The amino acid sequences of SCH-P9 and SCH-P10 were identified as Leu-Pro-Gly-Pro and Asp-Tyr-Val-Pro, with molecular weights of $382.46 \mathrm{Da}$ and $492.53 \mathrm{Da}$, respectively. An MTT assay, annexin V-fluorescein isothiocyanate (FITC) staining and cell cycle analysis were applied to identify the viability of cells, stages of apoptosis, and cell cycle distribution, respectively. SCH-P9 and SCH-P10 inhibited the growth of DU-145 and PC-3 cells in a dose- and time-dependent manner. Annexin V-FITC staining and flow cytometry analysis were employed to measure apoptosis and cell cycle arrest, respectively. SCH-P9 and SCH-P10 inhibited the growth of DU-145 cells by reducing the number of cells in $\mathrm{G}_{0} / \mathrm{G}_{1}$ phase, increasing the number in subG $\mathrm{G}_{1}$ phase and inducing apoptosis. SCH-P9 reduced the number of PC-3 cells in $\mathrm{subG}_{1}$ and $\mathrm{G}_{0} / \mathrm{G}_{1}$ phases, increased the number of cells in $\mathrm{G}_{2} / \mathrm{M}$ phase and induced apoptosis. SCH-P10 reduced the number of PC-3 cells in $G_{2} / M$ phase, increased the number of cells in $G_{0} / G_{1}$ phase and induced apoptosis. In conclusion, the results demonstrated that SCH-P9 and SCH-P10 induced apoptosis in DU-145 and PC-3 cells and may, therefore, exhibit potential for application in the treatment of prostate cancer.
\end{abstract}

Correspondence to: Professor Guofang Ding, Department of Pharmacy, School of Food Science and Pharmacy, Zhejiang Provincial Key Engineering Technology Research Center of Marine Biomedical Products, Zhejiang Ocean University, 1 Haida South Road, Lincheng, Changzhi Island, Zhoushan, Zhejiang 316000, P.R. China

E-mail: dgf2016@yeah.net

Key words: Sinonovacula constricta, proliferation, enzymatic hydrolysis, peptides, apoptosis

\section{Introduction}

In the last two decades, the demand for functional foods and nutraceuticals has increased significantly in China. In China, individuals are beginning to pay more attention to their own health, and self-health care awareness is increasing. Therefore, in order to satisfy consumer needs, bioactive peptides from various foods are isolated by enzymatic hydrolysis and their functional activities are being investigated $(1,2)$. Bioactive peptide hydrolysates have gained increasing attention due to their physiologic effects on cardiovascular, gastrointestinal, nervous and immune systems (3). The hydrolysates of numerous marine organisms, such as Pardachirus marmoratus (P. marmoratus; also known as the Red Sea Moses sole), have been demonstrated to possess significant antitumor activities (4). Cancer is a disease of worldwide importance. Its incidence in developed countries is increasing, and cancer is the second most common cause of mortality (5). In 2017, 1.69 million new cancer cases and 59,000 mortalities from cancer are projected to occur in the United States (6). Therefore, there is an urgent requirement for the development of novel tumor-targeted therapies that specifically and effectively target tumor cells with low toxicity to normal tissues (7-9).

Prostate cancer is one of the world's most commonly diagnosed cancer, and is second to lung cancer as the leading cause of cancer-associated mortality in men (6). In China, prostate cancer is currently the most common malignancy diagnosed in men, and is one of the ten most common cancers in urban areas (10). Prostate cancer has the seventh highest incidence rate, and it is the tenth leading cause of cancer-associated mortality in males residing in urban areas, with a mortality rate of 3.67/100,000 males in 2010 (11). During the early development of prostate carcinomas, the growth of prostate epithelial cells is androgen-dependent (5). Therefore, hormone therapy is a primary method used to treat patients with prostate cancer. However, a proportion of tumor cells become androgen-independent (12). Despite the improved efficacy of chemotherapy for the majority of cancer types over the last 30 years, the highly toxic effects of chemotherapeutic drugs, such as doxorubicin, have lead to a significant reduction in the quality of life of patients, which remains a formidable problem in clinical medicine (13). Therefore, the discovery and 
development of novel potent anticancer agents with minimal toxicity are in high demand.

In the present study, hydrolysates derived from the enzymatic hydrolysis of the common marine organism, Sinonovacula constricta ( $S$. constricta), were evaluated as a source of antitumor peptides. S. constricta is a commercially important bivalve that is used as food in China. In order to optimize its use for human consumption, and potentially gain higher value-added advantages, the authors of the present study focused on the utilization of $S$. constricta to obtain bioactive peptides and investigate their antitumor effects, with the aim of increasing the survival rates from cancer and enhancing the quality of life of patients. A number of bioactive peptides derived from marine organisms, such as the marine sponge, Jaspis jonhstoni, P. marmoratus, and somocystinamide A isolated from a Lyngbya majuscula/Schizothrix spp. marine cyanobacteria, have been demonstrated to possess significant antitumor activities (4,14-16). For instance, jasplakinolide (also known as jaspamide), a cyclic depsipeptide, inhibited human Jurkat $\mathrm{T}$ cell growth by inducing apoptosis (17). In addition, a short peptide isolated from the heated products of half-fin anchovy (Setipinna taty) peptide hydrolysates demonstrates antiproliferative activities against human PC-3 prostate cancer cells (18). However, the bioactivities of hydrolysates derived from $S$. constricta, particularly with regards to its nutraceutical and pharmaceutical applications, have not yet been reported. Therefore, the aim of the present study was to determine whether $S$. constricta might be a useful source of antitumor peptides obtained by enzymatic hydrolysis. Enzymatic hydrolysis was used to generate complex mixtures of similar molecular weight (MW) fractions, which were subsequently subject to ultrafiltration, and high-performance liquid chromatography (HPLC) was employed to obtain purified peptide fractions. The acquired peptides were evaluated for their antiproliferative properties using the colorimetric MTT assay. Peptides confirmed to possess potent antiproliferative activities were selected for identification of their amino acid composition and sequence. In addition, the mechanisms underlying the antiproliferative effects of identified peptides were investigated further.

\section{Materials and methods}

Materials. A total of $10 \mathrm{~kg} \mathrm{~S}$. constricta were obtained from Beimen market in Zhoushan City, (Zhejiang, China). The muscles were rapidly separated, and stored at $-80^{\circ} \mathrm{C}$. Trypsin, pepsin, papain, alcalase, acetonitrile and trifluoroacetic acid (TFA) were purchased from YTHX Biotechnology Co., Ltd. (Beijing, China; www.ythxbio.com). The MTT assay reagent was purchased from Beyotime Institute of Biotechnology (Nanjing, China). All additional reagents used were of analytical grade. Hormone-dependent DU-145 and PC-3 cell lines were obtained from the China Cell Bank of the Shanghai Institute of Biochemistry and Cell Biology (Shanghai, China). The annexin V-fluorescein isothiocyanate (FITC)/propidium iodide (PI) Apoptosis Detection and cell cycle staining kits were obtained from YTHX Biotechnology Co., Ltd.

Cell culture conditions. DU-145 and PC-3 cells were cultured in Ham's F-12 medium supplemented with $10 \%$ fetal calf serum
(FBS) (both Gibco; Thermo Fisher Scientific, Inc., Waltham, MA, USA) and $1 \%$ penicillin/streptomycin $(10,000 \mathrm{U} / \mathrm{ml}$ penicillin $\mathrm{G}$ sodium and $10,000 \mathrm{mg} / \mathrm{ml}$ streptomycin sulfate) (Thermo Fisher Scientific, Inc.). Cells were cultured in an incubator at $37^{\circ} \mathrm{C}$ and $5 \% \mathrm{CO}_{2}$ in a humidified atmosphere.

Preparation of $S$. constricta hydrolysates $(\mathrm{SCH})$. Hydrolysis of $S$. constricta muscles was performed using trypsin, pepsin, papain and alcalase enzymes. S. constricta meal (500 g) was homogenized using a tissue homogenizer and suspended in distilled water at a ratio of 1:2 $(\mathrm{m} / \mathrm{m})$. The homogenate was adjusted to the optimum conditions for digestion with trypsin, pepsin, papain or alcalase using $1.0 \mathrm{~N} \mathrm{NaOH}$ or $1.0 \mathrm{~N}$ HCI. The $S$. constricta homogenate was hydrolyzed using the four proteases at a concentration of $3 \%(\mathrm{~m} / \mathrm{m}$, enzyme/substrate), and at the $\mathrm{pH}$ and temperatures listed in Table I. The enzymatic hydrolysate mixtures were incubated for $5 \mathrm{~h}$ at $37^{\circ} \mathrm{C}$ in a thermostatic water bath. The enzymatic reactions were inactivated by heating the mixtures for $15 \mathrm{~min}$ at $100^{\circ} \mathrm{C}$. The mixture was centrifuged at $4,472 \times \mathrm{g}$ for $15 \mathrm{~min}$ at $4^{\circ} \mathrm{C}$, and the soluble fraction was collected. The resulting $\mathrm{SCH}$ were lyophilized and stored at $-80^{\circ} \mathrm{C}$ for downstream analysis.

Membrane fractionation. The SCH was isolated using the Amicon 8400 Stirred Ultrafiltration Unit (EMD Millipore, Billerica, MA, USA) with MW thresholds of 3, 5 and $8 \mathrm{KDa}$. Briefly, the freeze-dried SCH samples were diluted in distilled water (1:3) and the following fractions were collected: SCH-I, MW $\geq 8$ kDa; SCH-II, $5 \leq \mathrm{MW}<8 \mathrm{kDa}$; SCH-III, $3 \leq \mathrm{MW}<5$ $\mathrm{kDa}$; and $\mathrm{SCH}-\mathrm{IV}, \mathrm{MW}<3 \mathrm{kDa}$. The $\mathrm{SCH}$ group was the unfractionated sample. All SCH fractions were lyophilized and their antitumor activities were determined using DU-145 and PC-3 cells.

Gel filtration chromatography. The SCH fraction $(500 \mathrm{mg} / \mathrm{ml})$ exhibiting the highest antitumor activity following ultrafiltration, was further separated using Sephadex G-25 gel filtration media (YTHX Biotechnology Co., Ltd) and a gel filtration column $(2.5 \times 80 \mathrm{~cm} ; 75-180 \mu \mathrm{m})$, eluted with distilled water at a flow rate of $1 \mathrm{ml} / \mathrm{min}$ at room temperature. Each fraction was detected at $280 \mathrm{~nm}$. The SCH-IV fraction was further sub-fractionated into 5 groups, using G-25, by molecular weight. G-25 may be used to fractionate the molecules between 1 and $5 \mathrm{kDa}$. Bioactive fractions were collected by a computerized automatic collector (Shanghai Qingpu Huxi Instrument Factory, Shanghai, China) and lyophilized for an antitumor activity assay.

HPLC. The sample obtained from the Sephadex G-25 gel which demonstrated the highest antitumor activity was further purified by reverse-phase (RP)-HPLC using an Agilent 1260 Infinity system (Agilent Technologies, Inc., Santa Clara, USA) and a Zorbax SB-C18 column $(4.6 \times 250 \mathrm{~mm} ; 5 \mu \mathrm{m}$; Agilent Technologies, Inc.) and the column temperature was $30^{\circ} \mathrm{C}$. The mixture of acetonitrile (A) and $0.06 \%$ TFA (B) was used as mobile phase in linear gradient mode (5-30\% of A for $0-50 \mathrm{~min}$; $30-75 \%$ of A for $50-80 \mathrm{~min}$ ), with a flowrate of $0.8 \mathrm{ml} / \mathrm{min}$. Elution peaks were detected at $280 \mathrm{~nm}$, and were collected for determination of antitumor activity. The amino acid sequences of purified peptides were then determined. 
Amino acid sequence analysis and determination of molecular mass. A total of $200 \mu \mathrm{g}$ protein was mixed with $250 \mu \mathrm{l}$ rehydration solution and rehydrated for $14 \mathrm{~h}$ using an IPGphor (GE Healthcare, Beijing, China). The isoelectric focusing was achieved with four steps, then carried out by two-dimensional gel electrophoresis (19). Following pretreatment, the samples (50 pmol/20 $\mu \mathrm{l}$ ) were directly sequenced using a Shimadzu PPSQ-31A automated gas phase protein sequencer (Shimadzu Corporation, Kyoto, Japan). Briefly, samples were dissolved in $20 \mu \mathrm{l} \mathrm{CH}_{3} \mathrm{CN}$ (37\%; v/v) solution and applied to TFA-treated glass fiber membranes pre-treated with polybrene (Shimadzu Corporation). Data were recorded using Shimadzu PPSQ version 31A software (Shimadzu Corporation). An accurate molecular mass of SCH-P9 and SCH-P10 peptides was determined using an LTQ FT Ultra mass spectrometer (Thermo Fisher Scientific, Inc.). The ${ }^{1} \mathrm{H}$ nuclear magnetic resonance (NMR) and 13C NMR spectra were recorded in d-dimethyl sulfoxide (DMSO) on a Bruker AV-400 spectrometer (Bruker Corporation, Billerica, MA, USA) at working frequencies 400 and $100 \mathrm{MHz}$. Chemical shifts are expressed in parts per million $(\delta)$ values and coupling constants $(J)$ in Hz. High resolution electrospray ionization mass spectrometry (HRESI-MS) were measured on the LTQ FT Ultra instrument. The above procedure was performed by Wuhan Moon Biosciences Co., Ltd. (Wuhan, China).

MTT assay. The effects of SCH on cell viability were determined using a colorimetric MTT assay. Briefly, DU-145 and PC-3 cells were seeded at a density of $1 \times 10^{4}$ cells/well in 96-well plates, and incubated for $24 \mathrm{~h}$ to allow cells to adhere to the surface of the plates in a humidified atmosphere, in a $5 \% \mathrm{CO}_{2}$ incubator at $37^{\circ} \mathrm{C}$ (Forma; Thermo Fisher Scientific, Inc.). The DU-145 and PC-3 cells were then treated with $\mathrm{SCH}$ at $1,5,10 \mathrm{mg} / \mathrm{ml}$ for $24 \mathrm{~h}$. DU-145 and PC-3 control cells were treated with F-12 culture medium. Cell viability was detected by adding MTT reagent. A total of $20 \mu \mathrm{l}$ MTT solution was added to each well for an additional 4-5 h at $37^{\circ} \mathrm{C}$. Following the addition of the DMSO solution $(150 \mu \mathrm{l})$ to each well to dissolve the formazan crystals, the optical density (OD) was read at a wavelength of $450 \mathrm{~nm}$ using a Model 680 Microplate Reader (Bio-Rad Laboratories, Inc., Hercules, CA, USA). Three independent experiments were performed, and the cell inhibitory rate (A value) was determined using the following equation: Inhibition $(\%)=\left[\left(\mathrm{OD}_{\text {control }}-\mathrm{OD}_{\text {treated }}\right) /\left(\mathrm{OD}_{\text {control }}-\mathrm{OD}_{\text {blank }}\right) \times 100\right]$.

Cell cycle analysis. Cell cycle analysis and measurement of cellular DNA content were performed following synchronization. Synchronization was achieved by incubating DU-145 and PC-3 cells in $0.5 \%$ FBS F-12 medium for $48 \mathrm{~h}$ in a humidified atmosphere with $5 \% \mathrm{CO}_{2}$ at $37^{\circ} \mathrm{C}$. DU-145 and PC-3 cells were seeded in six-well plates $\left(1 \times 10^{5}\right.$ cells/well) and allowed to adhere overnight. DU-145 cells were treated with SCH-P9 (1.21 mg/ml), SCH-P10 (1.41 mg/ml) and fluorouracil (5-FU; $2.02 \mu \mathrm{g} / \mathrm{ml})$ for $24 \mathrm{~h}$. PC-3 cells were treated with SCH-P9 $(1.09 \mathrm{mg} / \mathrm{ml}), \mathrm{SCH}-\mathrm{P} 10(0.91 \mathrm{mg} / \mathrm{ml})$ and 5-FU $(2.14 \mu \mathrm{g} / \mathrm{ml})$ for $24 \mathrm{~h}$. For cell cycle analysis, cells were first collected by trypsinization, fixed in $70 \%$ ethanol, washed in cold phosphate-buffered saline (PBS; pH 7.4) and then stained with PI solution $(50 \mu \mathrm{g} / \mathrm{ml} \mathrm{PI,} 100 \mu \mathrm{g} / \mathrm{ml}$ RNase and $0.1 \%$ Triton X-100
Table I. Optimum conditions for the enzymatic digestion of Sinonovacula constricta using four proteinases.

\begin{tabular}{lcc}
\hline & \multicolumn{2}{c}{ Optimum conditions } \\
\cline { 2 - 3 } Proteinase & $\mathrm{pH}$ & Temperature $\left({ }^{\circ} \mathrm{C}\right)$ \\
\hline Trypsin & 7.5 & 37 \\
Pepsin & 2.0 & 37 \\
Papain & 6.0 & 37 \\
Alcalase & 8.0 & 37 \\
\hline
\end{tabular}

Table II. Effect of different enzymatic Sinonovacula constricta hydrolysates on the percentage growth inhibition of human prostate cancer cell lines.

\begin{tabular}{lcc}
\hline Enzymatic lysate & DU-145 $(\%)$ & PC-3 $(\%)$ \\
\hline Trypsin & $33.67 \pm 2.3$ & $48.23 \pm 6.3$ \\
Pepsin & $86.24 \pm 3.5$ & $88.21 \pm 7.3$ \\
Papain & $45.26 \pm 5.4$ & $44.75 \pm 1.4$ \\
Alcalase & $69.32 \pm 5.6$ & $67.28 \pm 7.1$ \\
\hline
\end{tabular}

in PBS) for $30 \mathrm{~min}$ in the dark at room temperature. The DNA content of DU-145 and PC-3 cells was analyzed using a Guava easyCyte Flow Cytometer (EMD Millipore). Histograms showing the population of cells in each cell cycle phase based on DNA content were constructed using GuavaSoft software (version, 4.20; EMD Millipore). A total of three independent experiments were performed, and the results are presented as the mean \pm standard deviation.

Cell apoptosis analysis. Cell apoptosis detection was performed using fluorescence-activated cell sorting (FACS) analysis. The exposure of phosphatidylserine on the extracellular side of the cell membrane was quantified by annexin V-FITC/PI staining. DU-145 and PC-3 cells were seeded in six-well plates $\left(1 \times 10^{5}\right.$ cells/well). DU-145 cells were treated with SCH-P9 $(1.21 \mathrm{mg} / \mathrm{ml}), \mathrm{SCH}-\mathrm{P} 10(1.41 \mathrm{mg} / \mathrm{ml})$ or $5-\mathrm{FU}$ $(2.02 \mu \mathrm{g} / \mathrm{ml})$ for $24 \mathrm{~h}$. PC-3 cells were treated with SCH-P9 (1.09 mg/ml), SCH-P10 (0.91 mg/ml) or 5-FU $(2.14 \mu \mathrm{g} / \mathrm{ml})$ for $24 \mathrm{~h}$. The cells were collected by trypsinization. Following centrifugation at $213 \mathrm{x} \mathrm{g}$ at $4^{\circ} \mathrm{C}$ for $5 \mathrm{~min}$, cell pellets were washed twice with cold PBS. Cells were then incubated with $5 \mu \mathrm{l}$ annexin V-FITC and $10 \mu \mathrm{l}$ PI (Shanghai BestBio, Shanghai, China), according to the manufacturer's protocol, at room temperature for $15 \mathrm{~min}$ in the dark. Binding buffer (400 $\mu \mathrm{l} ; 1 \mathrm{X})$ was subsequently added to each tube and the cells were immediately analyzed using a Guava easyCyte Flow Cytometer (EMD Millipore). The data were analyzed using GuavaSoft software (version, 4.20; EMD Millipore).

Statistical analysis. Data are presented as the mean \pm standard deviation of at least three independent experiments. Data were analyzed by one-way repeated measures analysis of variance with Tukey test using SPSS software (version 16; SPSS, Inc., 

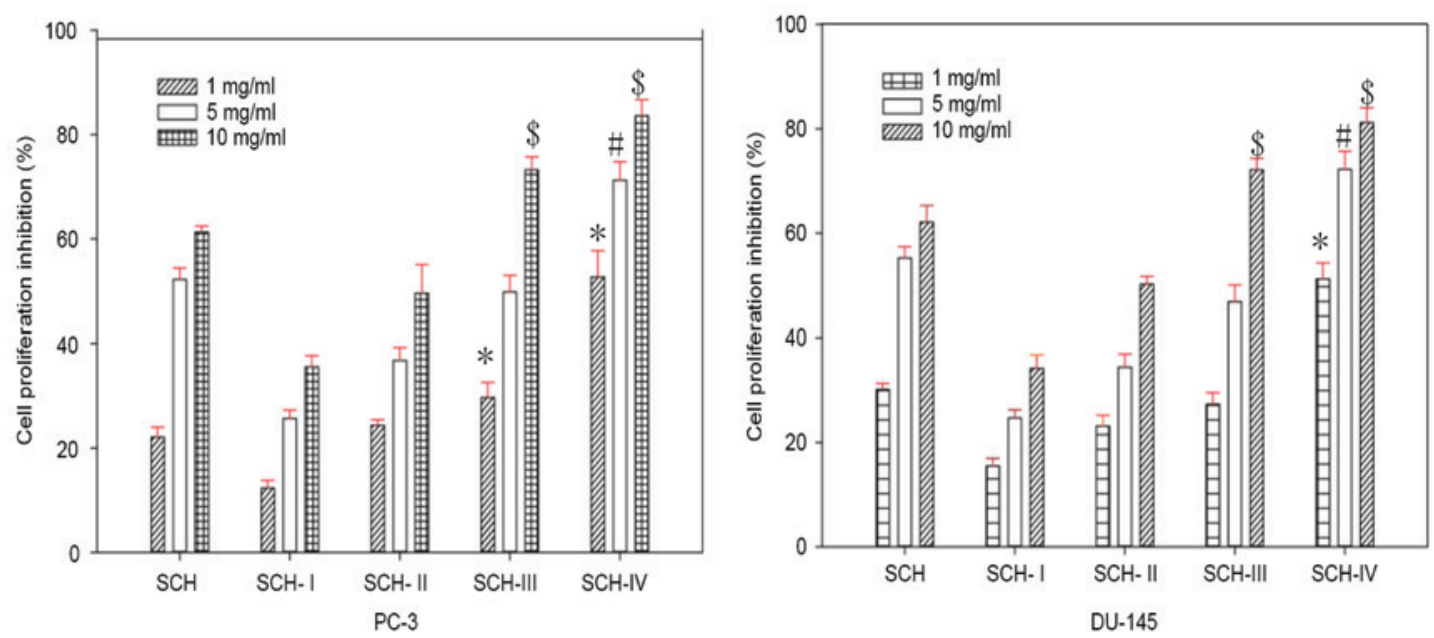

Figure 1. Effect of SCH and different fractions separated by ultrafiltration on the growth of PC-3 and DU-145 prostate cancer cells. ${ }^{*} \mathrm{P}<0.05 \mathrm{vs} .1 \mathrm{mg} / \mathrm{ml} \mathrm{SCH}$, ${ }^{\text {"P }}<0.05$ vs. $5 \mathrm{mg} / \mathrm{ml} \mathrm{SCH},{ }^{\$} \mathrm{P}<0.05$ vs. $10 \mathrm{mg} / \mathrm{ml} \mathrm{SCH}$. SCH, Sinonovacula constricta hydrolysates.

Chicago, IL, USA). P $<0.05$ was considered to indicate a statistically significant difference.

\section{Results}

Preparation of S. constricta enzymatic hydrolysates. SCHs were produced by incubating the organisms with trypsin, pepsin, papain or alcalase enzymes under optimal conditions (Table I). The antitumor activities of the hydrolysates were assessed using an MTT assay and the results are shown in Table II. Out of all hydrolysates, the pepsin hydrolysate exhibited the highest antiproliferative activity against DU-145 and PC-3 human prostate cancer cell lines (Table II). Therefore, the pepsin hydrolysate was selected for further study.

Ultrafiltration of SCH. SCHs were fractionated by MW using an ultrafiltration membrane bioreactor system, with MW thresholds of 8,5 and $3 \mathrm{kDa}$. Therefore, four different fractions were obtained and divided into SCH-I, (MW $\geq 8 \mathrm{kDa}$ ), SCH-II $(5 \leq \mathrm{MW}<8 \mathrm{kDa})$, SCH-III $(3 \leq \mathrm{MW}<5 \mathrm{kDa})$ and $\mathrm{SCH}-\mathrm{IV},(\mathrm{MW}<3 \mathrm{kDa}$ ) groups. The $\mathrm{SCH}$ group was treated with the unfractionated sample. SCH, SCH-I, SCH-II, SCH-III and SCH-IV inhibited the growth of DU-145 and PC-3 cells in a dose-dependent manner (Fig. 1). In addition, SCH-IV exhibited the highest antiproliferative activity among all of the fractions (Fig. 1). Therefore, SCH-IV was selected for further purification by gel filtration chromatography.

Gel filtration chromatography of the SCH-IV fraction. As shown in Fig. 2A, SCH-IV was further separated into five fractions, termed SCH-IV-1, SCH-IV-2, SCH-IV-3, SCH-IV-4 and SCH-IV-5. Out of all fractions examined, SCH-IV-5 demonstrated the greatest inhibitory effect on the growth of DU-145 and PC-3 cells (Fig. 2B). Therefore, SCH-IV-5 was selected for further purification by HPLC to isolate and characterize the peptides responsible for the observed antiproliferative effects.

Isolation of peptides from SCH-IV-5 by RP-HPLC. SCH-IV-5 was further purified by RP-HPLC. As shown in Fig. 3, SCH-IV-5 was separated into 12 fractions, termed SCH-P1,

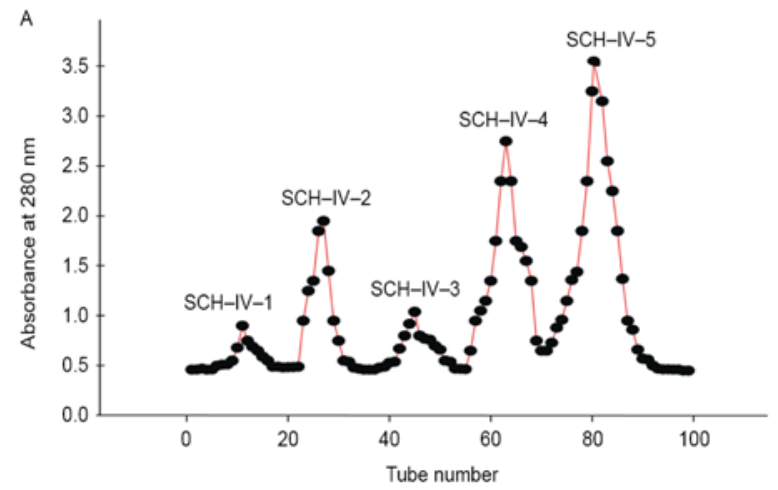

B

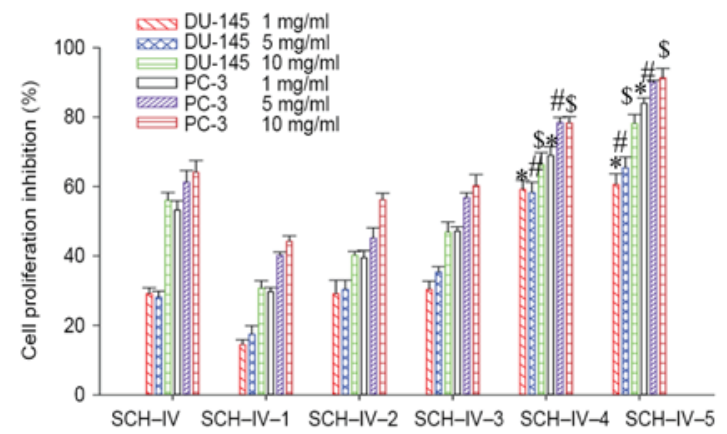

Figure 2. (A) Gel filtration chromatography of the SCH-IV fraction using a Sephadex G-15 column. (B) The effect of increasing concentrations of SCH-IV on the growth of DU-145 and PC-3 cells. The results are expressed as the mean \pm standard deviation, and each experiment was performed in triplicate. ${ }^{*} \mathrm{P}<0.05$ vs. $1 \mathrm{mg} / \mathrm{ml} \mathrm{SCH}-\mathrm{IV},{ }^{\#} \mathrm{P}<0.05$ vs. $5 \mathrm{mg} / \mathrm{ml} \mathrm{SCH}-\mathrm{IV}$, ${ }^{\$} \mathrm{P}<0.05$ vs. $10 \mathrm{mg} / \mathrm{ml} \mathrm{SCH}-\mathrm{IV}$. SCH, Sinonovacula constricta hydrolysates.

SCH-P2, SCH-P3, SCH-P4, SCH-P5, SCH-P6, SCH-P7, SCH-P8, SCH-P9, SCH-P10, SCH-P11 and SCH-P12, and their antiproliferative effects on DU-145 and PC-3 cells were investigated. The antiproliferative activities of SCH-P9 and SCH-P10 peptides were greater when compared with the remaining 10 peptides. Therefore, SCH-P9 and SCH-P10 were considered to be the peptides exhibiting the greatest antitumor activity, and their sequences were identified as Leu-Pro-Gly-Pro and Asp-Tyr-Val-Pro, respectively (Fig. 4). The purity of SCH-P9 

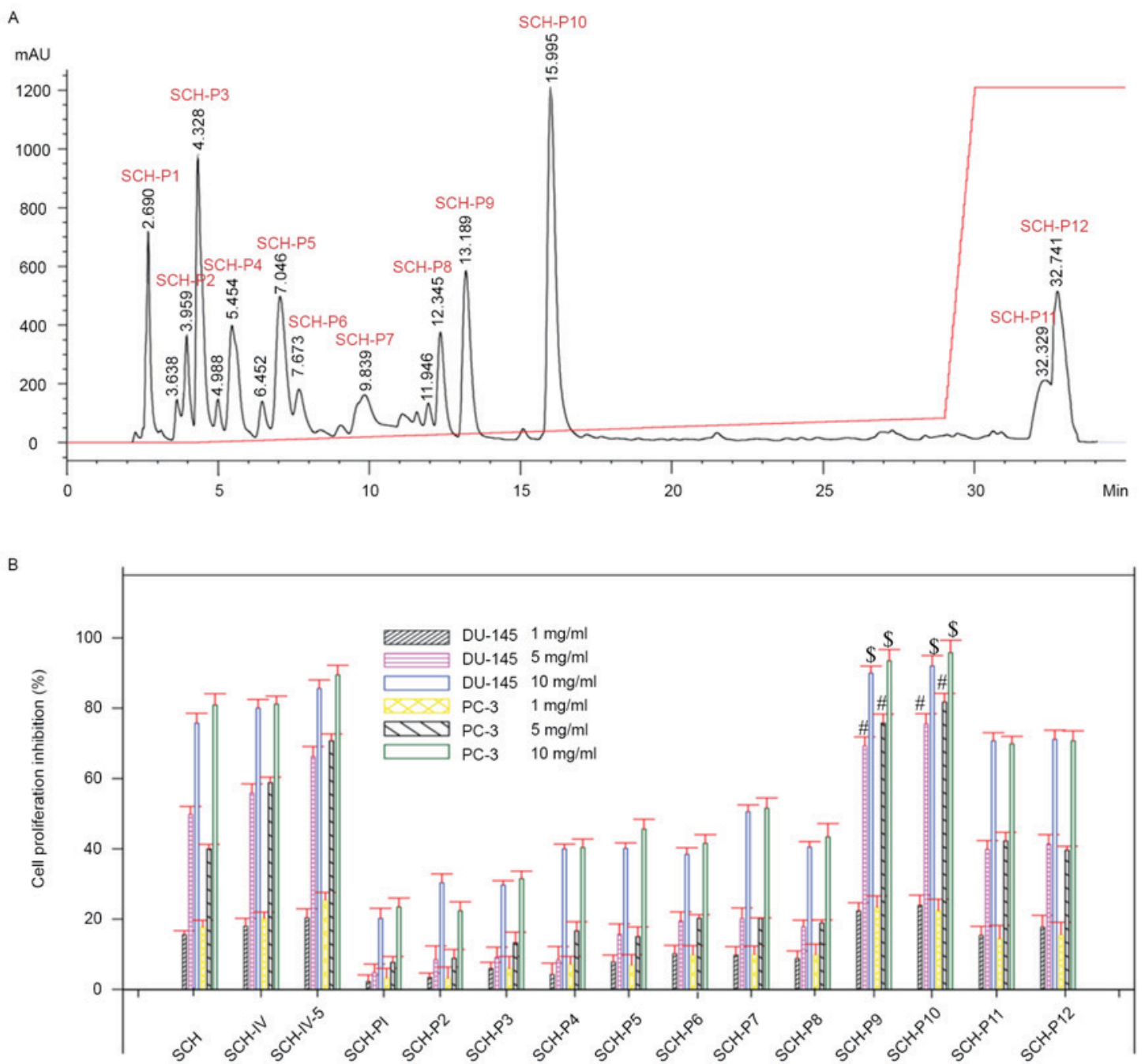

Figure 3. (A) A chromatogram showing the 12 fractions of SCH-IV-5 separated by reverse-phase-high-performance liquid chromatography using a Zorbax SB-C18 column. (B) The effect of increasing concentrations of SCH-IV-5 fractions on the growth of DU-145 and PC-3 prostate cancer cells. "P<0.05 vs. $1 \mathrm{mg} / \mathrm{ml} \mathrm{SCH}-\mathrm{IV}-5,{ }^{,} \mathrm{P}<0.05$ vs. $5 \mathrm{mg} / \mathrm{ml} \mathrm{SCH}-\mathrm{IV}-5,{ }^{,} \mathrm{P}<0.05$ vs. $10 \mathrm{mg} / \mathrm{ml} \mathrm{SCH}-\mathrm{IV}-5$. SCH, Sinonovacula constricta hydrolysates.

and SCH-P10 were 95.99 and $96.99 \%$, and the yields were 5.79 and $8.92 \%$, respectively.

Growth inhibition rate of DU-145 and PC-3 cells following treatment with SCH-P9 and SCH-P1O. DU-145 and PC-3 cells were exposed to $0.1,0.5,1.0,5.0$, and $10 \mathrm{mg} / \mathrm{ml} \mathrm{SCH}-\mathrm{P} 9$ or SCH-P10 for 6, 12 or $24 \mathrm{~h}$. At all doses examined, SCH-P9 and SCH-P10 effectively inhibited the growth of DU-145 and PC-3 cells at 6, 12, and $24 \mathrm{~h}$ (Fig. 5A and B). A time- and dose-dependent increase in the growth inhibition rate of DU-145 and PC-3 cells treated with SCH-P9 and SCH-P10 was observed (Fig. 5A and B). The maximal inhibitory concentration $\left(\mathrm{IC}_{50}\right)$ of SCH-P9 on DU-145 cells was 12.66, 5.45 and $1.21 \mathrm{mg} / \mathrm{ml}$ at 6,12 and $24 \mathrm{~h}$, respectively. The $\mathrm{IC}_{50}$ of SCH-P10 on DU-145 cells was $11.28,5.49$ and $1.41 \mathrm{mg} / \mathrm{ml}$ at 6,12 and $24 \mathrm{~h}$, respectively. The $\mathrm{IC}_{50}$ of SCH-P9 on PC-3 cells was $12.09,5.96$ and $1.09 \mathrm{mg} / \mathrm{ml}$ at 6,12 and $24 \mathrm{~h}$, respectively. The $\mathrm{IC}_{50}$ of SCH-P10 on PC-3 cells was 10.94, 5.12 and $0.91 \mathrm{mg} / \mathrm{ml}$ at 6,12 and $24 \mathrm{~h}$, respectively. Of particular note, SCH-P9 and SCH-P10 did not inhibit the growth of DU-145 and PC-3 cells to a greater extent when compared with 5-FU under a similar growth inhibition rate (Fig. 5C).
Effect of SCH-P9 and SCH-P1O on the cell cycle distribution of DU-145 and PC-3 cells. In order to investigate the mechanisms responsible for SCH-P9- and SCH-P10-mediated cell growth inhibition, the cell cycle distribution of DU-145 and PC-3 cells were evaluated by flow cytometry. A representative example indicating the effect of SCH-P9 and SCH-P10 treatment for $24 \mathrm{~h}$ on cell cycle phase distribution is shown in Fig. 6. When compared with the untreated cells, treatment with SCH-P10 was associated with an increase in the number of DU-145 cells in the sub-G1 phase, together with a concomitant increase in the proportion of cells in the $G_{0} / G_{1}$ phase, and a decrease in the number of cells in $S$ and $G_{2} / M$ phases (Fig. 6). However, there were no significant changes in the cell cycle distribution of DU-145 cells following treatment with SCH-P9. When compared with untreated controls, $\mathrm{SCH}-\mathrm{P} 9$ reduced the number of PC-3 cells in $\mathrm{subG}_{1}$ and $\mathrm{G}_{0} / \mathrm{G}_{1}$ phases, whereas an increased number were observed in the $\mathrm{G}_{2} / \mathrm{M}$ phase; however, these alterations did not reach statistical significance (Fig. 6). SCH-P10 treatment significantly reduced the number of PC-3 cells in $\mathrm{G}_{2} / \mathrm{M}$ phase, and significantly increased the number in $G_{0} / G_{1}$ phase when compared with untreated controls (Fig. 6). 

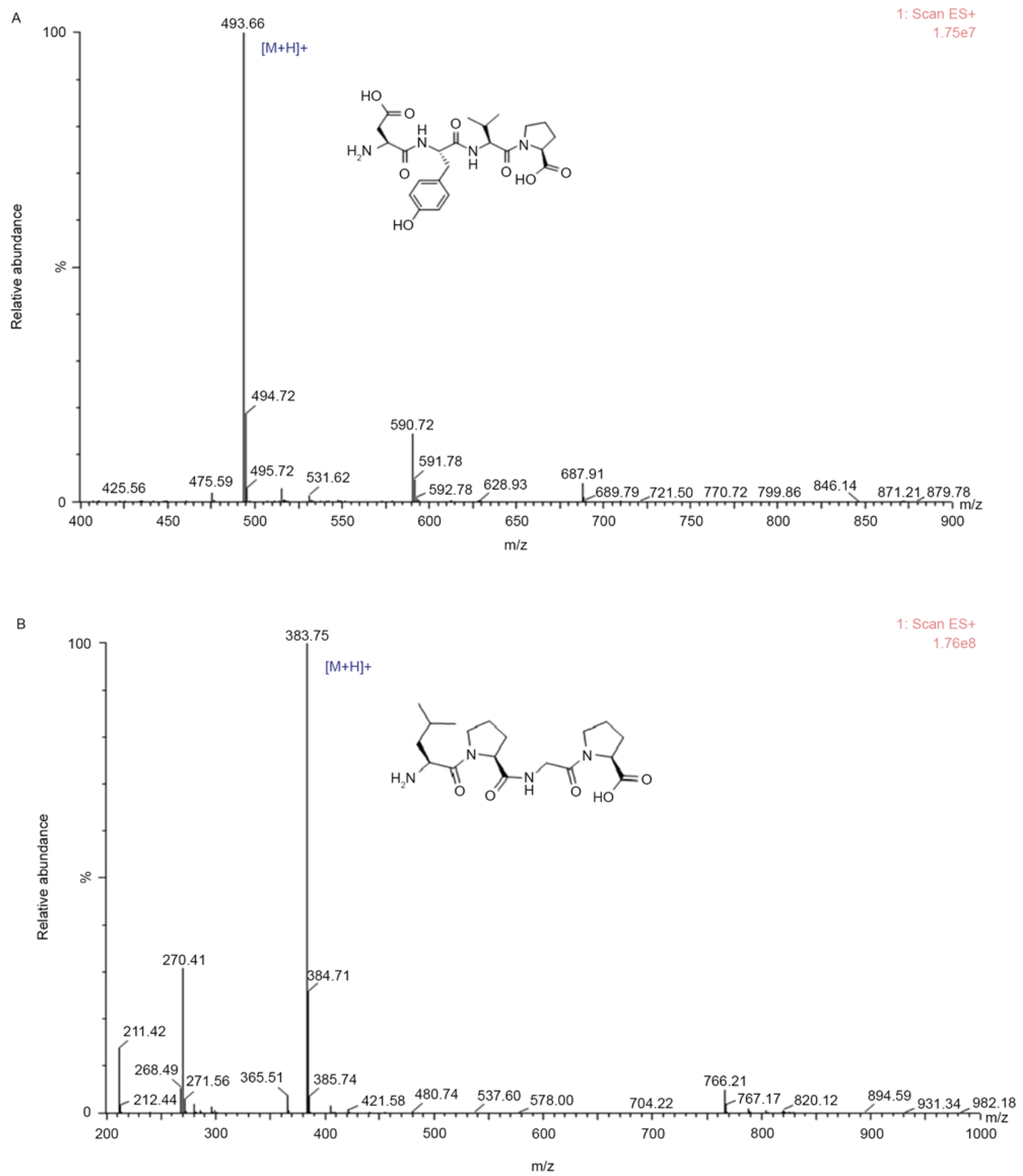

Figure 4. Mass spectroscopy analysis of (A) SCH-P9 and (B) SCH-P10 fractions. SCH-P9 and SCH-P10 sequences were identified as Leu-Pro-Gly-Pro and Asp-Tyr-Val-Pro, respectively, and their molecular structures are shown. SCH, Sinonovacula constricta hydrolysates.

SCH-P9 and SCH-P10 induced apoptosis of DU-145 and PC-3 cells. In order to determine whether the observed alterations in prostate cancer cell cycle distributions following treatment with SCH-P9 and SCH-P10 were due to increased levels of apoptosis, treated DU-145, and PC-3 cells were stained with annexin V-FITC/PI and analyzed by flow cytometry. As shown in Fig. 7, treatment of DU-145 and PC-3 cells with SCH-P9 and $\mathrm{SCH}-\mathrm{P} 10$ for $24 \mathrm{~h}$ was associated with a significant increase in early apoptosis rates when compared with untreated control cells. The percentage of DU-145 cells in early apoptosis following treatment with $2.02 \mu \mathrm{g} / \mathrm{ml} 5-\mathrm{FU}$ was $26.71 \%$, which was significantly lower than the percentage of DU-145 cells in early apoptosis following treatment with $1.41 \mathrm{mg} / \mathrm{ml} \mathrm{SCH}-\mathrm{P} 10$ (Fig. 7). However, the percentage of DU-145 cells in late apoptosis following treatment with $2.02 \mu \mathrm{g} / \mathrm{ml} \mathrm{5-FU}$ was $40.95 \%$, which was higher than the number of cells in late apoptosis following treatment with $1.41 \mathrm{mg} / \mathrm{ml} \mathrm{SCH}-\mathrm{P} 10$. Similar alterations in the number of PC-3 cells in early and late apoptosis 

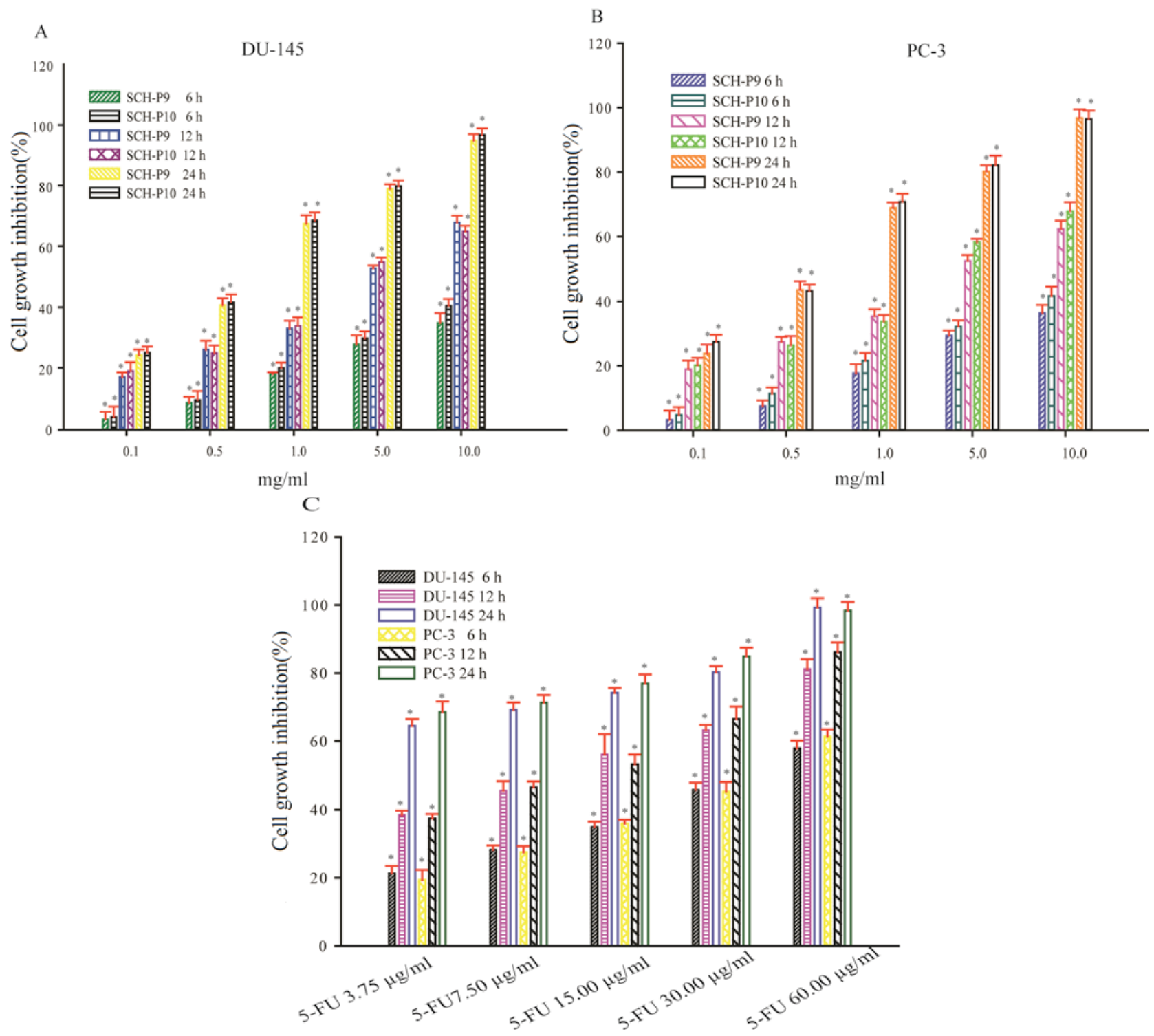

Figure 5. Effect of increasing concentrations of (A) SCH-P9, (B) SCH-P10 and (C) 5-FU on the growth of DU-145 and PC-3 cells for 6, 12 and 24 h. The percentage cell growth inhibition is presented relative to untreated controls ( $0 \%$ inhibition). An MTT assay was used to measure cell growth following treatment with SCH fractions and 5-FU. The results are expressed as the mean \pm standard deviation, and each experiment was performed in triplicate. "P $<0.05$ vs. untreated controls. SCH, Sinonovacula constricta hydrolysates; 5-FU, fluorouracil.

following treatment with 5-FU and SCH-P10 were observed (Fig. 7).

\section{Discussion}

Bioactive peptides obtained by enzymatic hydrolysis are gaining increased attention due to their unique amino acid compositions, and they may hold promise for a wide range of therapeutic applications (20). Bioactive peptides may reduce disease risk and promote human health (20). Peptides that induce apoptosis of tumor cells are considered to be effective anticancer agents.

Anticancer peptides derived from marine sources and their potential use as alternative anticancer treatments has been well established. For instance, a novel peptide derived from Ruditapes philippinarum, with an N-terminal amino acid sequence identified as Ala-Val-Leu-Val-Asp-Lys-Gln-Cys-ProAsp, effectively induces apoptosis of prostate cancer cells (21).
In addition, Ala-Phe-Asn-Ile-His-Asn-Arg-Asn-Leu-Leu, a decapeptide derived from the pepsin hydrolysates of the Mytilus coruscus shellfish, has been demonstrated to exhibit anticancer properties (22).

In the present study, a low MW peptide derived from the hydrolysate of $S$. constricta was observed to exhibit the strongest inhibitory effects on the growth of DU-145 and PC-3 cells, and was therefore purified further. A number of previous studies have demonstrated that bioactive peptides are primarily low MW peptides (23-25). The sepia ink oligopeptide, a tripeptide extracted from Sepia ink (Sepia esculenta), induces apoptosis of prostate cancer cell lines via caspase-3 activation and elevation of the $\mathrm{Bcl}-2$ like protein 4/B-cell lymphoma-2 (Bcl-2) ratio (26).

In the current study, $\mathrm{SCH}-\mathrm{P} 9$ and $\mathrm{SCH}-\mathrm{P} 10$ fractions inhibited the growth of PC-3 and DU-145 cells to a greater extent when compared with the other $\mathrm{SCH}$ fractions. The peptide size and composition of the amino acids in protein hydrolysates 
A

DU-145

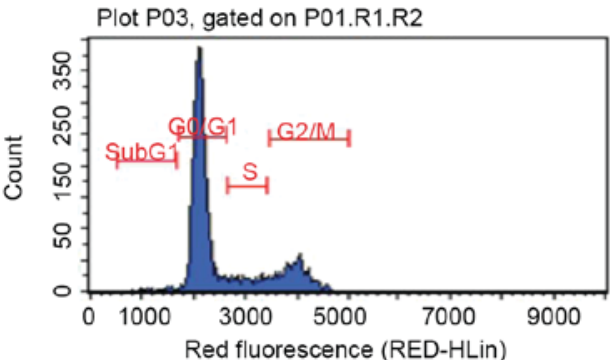

PC-3

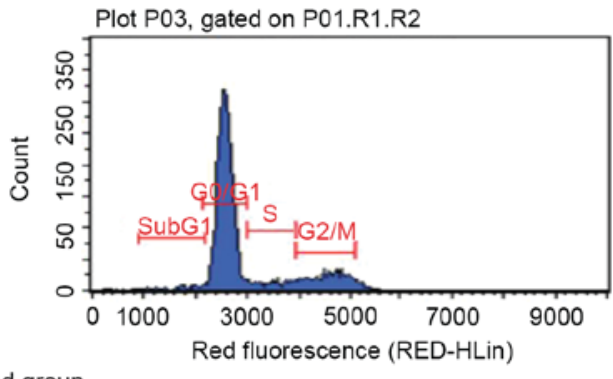

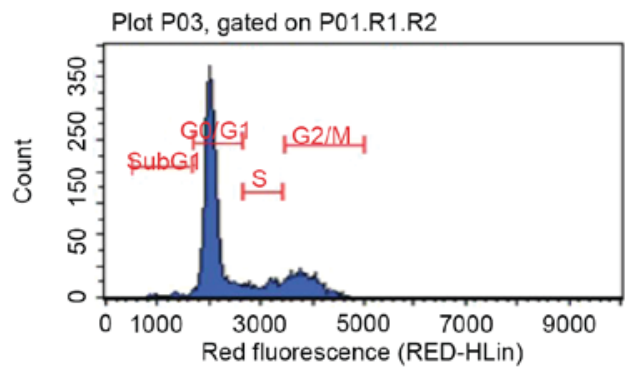

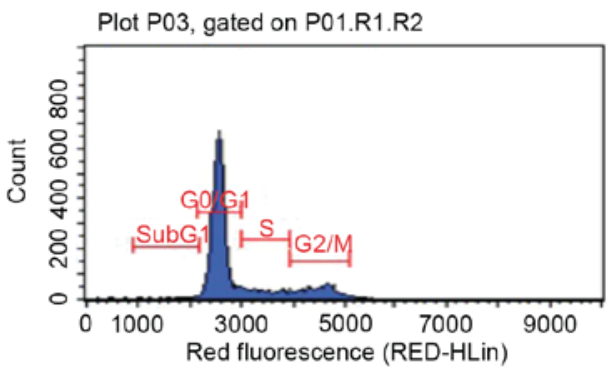

$\mathrm{SCH}-\mathrm{P9} 1.21 \mathrm{mg} / \mathrm{ml}$

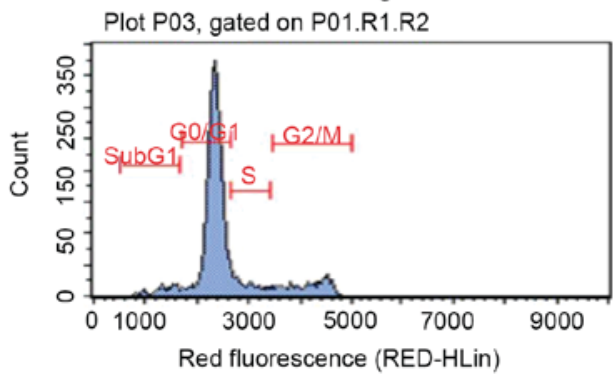

SCH-P9 1.04 mg/m

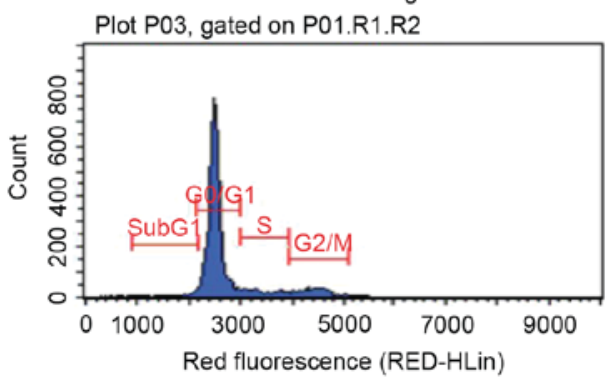

SCH-P10 $1.41 \mathrm{mg} / \mathrm{ml}$

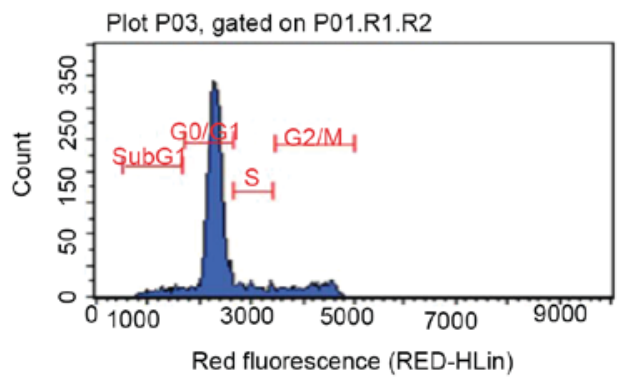

$5-\mathrm{FU} 2.02 \mu \mathrm{g} / \mathrm{ml}$

B

DU-145
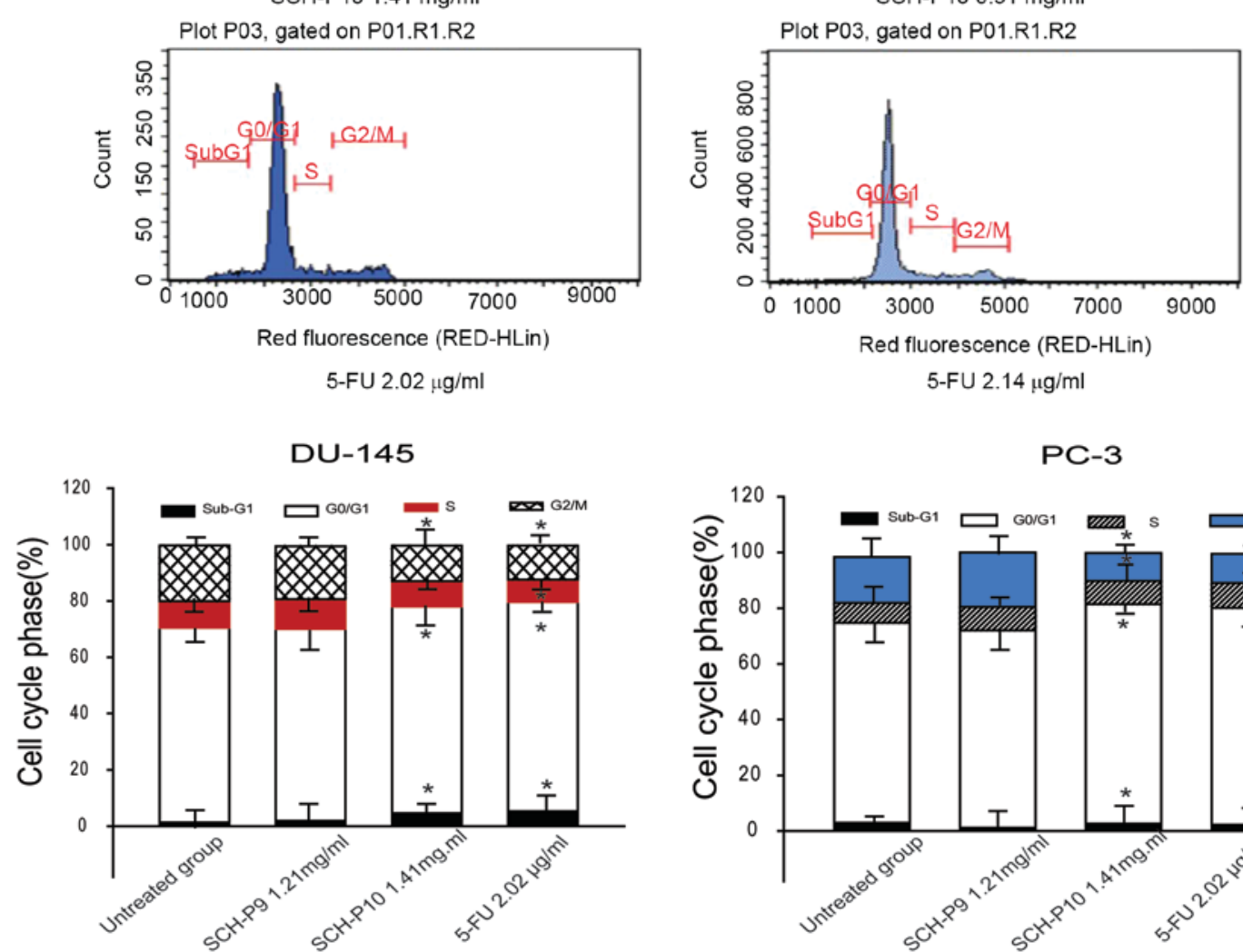

PC-3

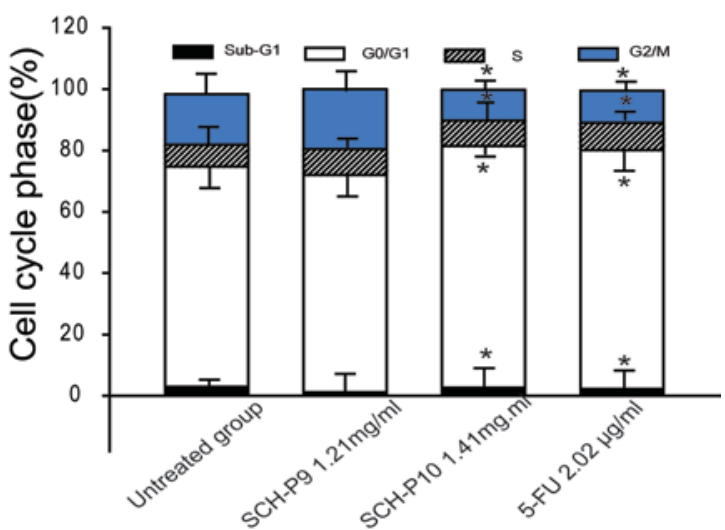

Figure 6. (A) Cell cycle distribution profiles and of DU-145 and PC-3 cells following treatment with SCH-P9, SCH-P10 or 5-FU for 24 h. (B) Stacked column graphs showing the percentage of DU-145 and PC-3 cells in each cell cycle phase following treatment with SCH-P9, SCH-P10 or 5-FU for 24 h. Data are expressed as the mean \pm standard deviation $(\mathrm{n}=3)$. ${ }^{*} \mathrm{P}<0.05$ vs. untreated group. $\mathrm{SCH}$, Sinonovacula constricta hydrolysates; 5-FU, fluorouracil. 
DU-145

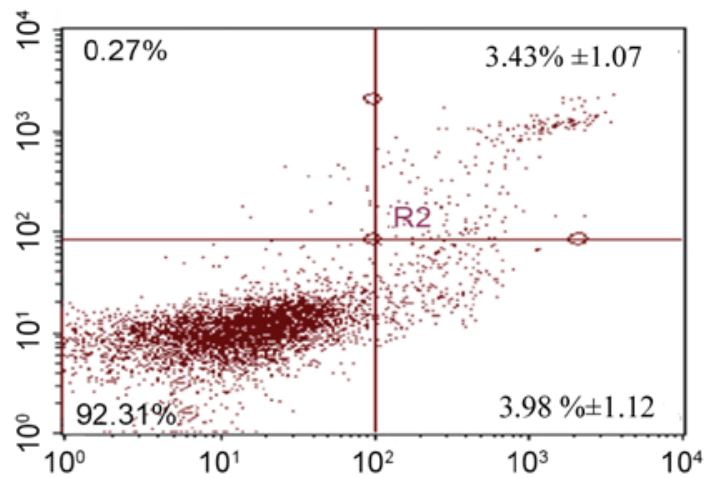

PC-3

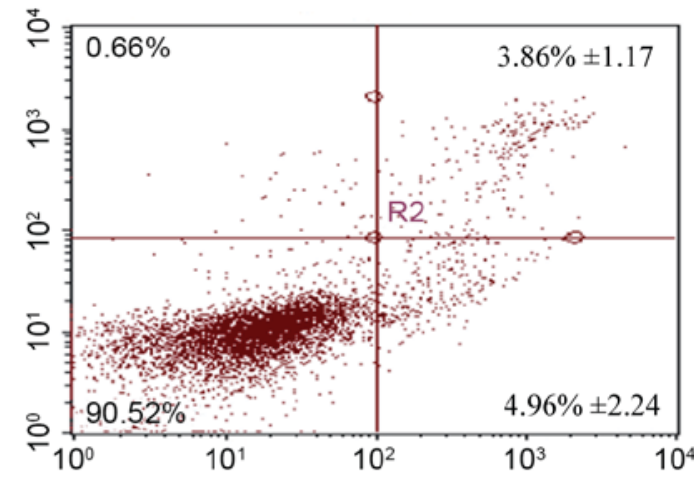

Untreated group
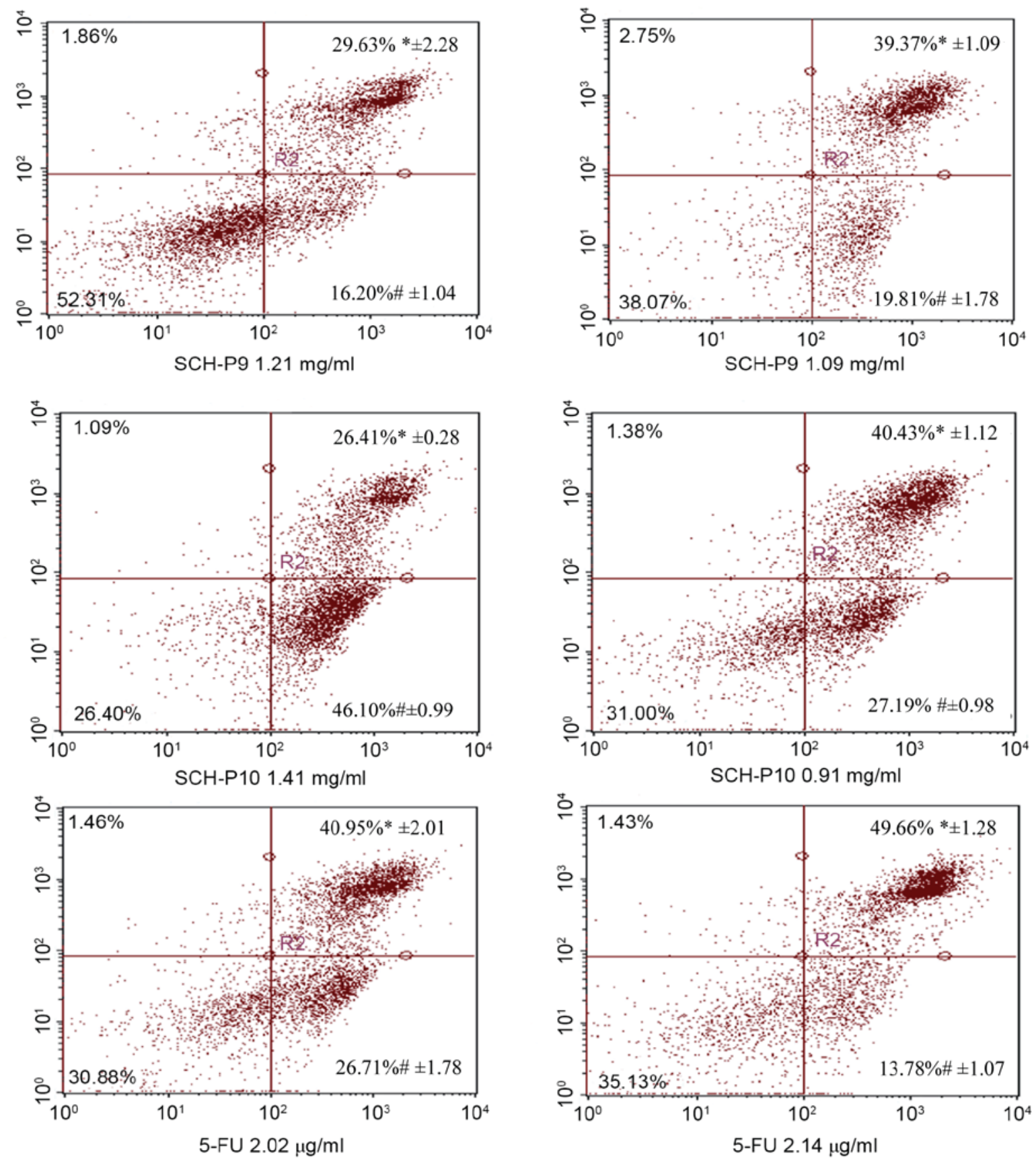

\section{Annexin V FITC}

Figure 7. Apoptosis of DU-145 and PC-3 cells following treatment with SCH-P9, SCH-P10 or 5-FU for 24 h as determined by annexin-FITC/PI staining and FACS analysis. Plots from one of three independent FACS assays are shown. ${ }^{*} \mathrm{P}<0.05$ vs. untreated group in late apoptosis; ${ }^{\sharp} \mathrm{P}<0.05$ vs. untreated group in early apoptosis. SCH, Sinonovacula constricta hydrolysates; 5-FU, fluorouracil; FITC, fluorescein isothiocyanate; PI, propidium iodide; FACS, fluorescence-activated cell sorting. 
serve crucial roles in their cell inhibitory activity (27). The $\mathrm{N}$-terminal amino acid sequence and molecular mass of SCH-P9 and SCH-P10 were determined using a Shimadzu PPSQ-31A automated gas phase sequencer followed by a Thermo Fisher Scientific LTQ FT Ultra mass spectrometer. The sequences of SCH-P9 and SCH-P10 were identified as Leu-Pro-Gly-Pro (MW, $382.46 \mathrm{Da}$ ) and Asp-Tyr-Val-Pro (MW, $492.53 \mathrm{Da}$ ), respectively. The SCH-P9 and SCH-P10 peptides were effective against the growth of PC-3 and DU-145 cells in a time and dose-dependent manner. Lower MW peptides demonstrate greater molecular mobility and diffusivity when compared with higher MW peptides, which contributes to enhanced interactions with cancer cell components and therefore increases anticancer activities (28).

A number of peptides obtained from marine animal species have been demonstrated to exert strong antitumor activities, including didemnin $\mathrm{B}$, keenamide $\mathrm{A}$, kahalalide F, jasplakinolide, aurilide and theopedirn B (17). These antitumor compounds possess tumor-targeting abilities, with lower toxicity in normal tissues. The properties of these anticancer peptides make them promising therapeutic agents, as functional food ingredients or antitumor drugs that may be used for cancer prevention and/or treatment. Therefore, investigating anticancer peptides, such as SCH-P9 and SCH-P10, may be important for the development of novel cancer prevention and treatment strategies. Future studies investigating the molecular structure and antitumor mechanisms of SCH-P9 and SCH-P10 may promote the emergence of tetrapeptides as novel functional food ingredients or antitumor drugs.

In recent years, an increasing number of marine anticancer peptides have been identified. For instance, jasplakinolide, which is a cyclic depsipeptide with a 15-carbon macrocyclic ring, was isolated from marine sponge Jaspis splendens (29). This peptide induced apoptosis HCT-116 and HeLa cells by activating caspase- 3 and decreasing $\mathrm{Bcl}-2$ protein expression (29). Analogs of jasplakinolide, such as jasplakinolide B, C, and V, isolated from Jaspis. splendens have demonstrated anticancer activities in NCI60 cells (29). It has been reported that dolastatin 10 , isolated from the marine mollusk Dolabella auricularia, is a linear pentapeptide that inhibits the proliferation of murine L1210 leukemia cells $(12,17,30)$. In addition, the growth-inhibiting effects of this peptide were associated with induction of apoptosis via increasing p53 and decreasing Bcl-2 expression levels. Similarly, SCH-P9 and SCH-P10 were demonstrated to serve a role in increasing apoptosis of prostate cancer cells. An increase in PI and annexin V staining in DU-145 and PC-3 cells was observed following treatment with SCH-P9 and SCH-P10 for $24 \mathrm{~h}$, which indicates that SCH-P9 and SCH-P10 induces apoptosis of prostate cancer cells.

The acquisition of novel anticancer peptides from marine sources has gained significant attention due to potential therapeutic applications. Foodstuffs that improve the state of health and/or reduce the risk of disease are defined as functional foods (31). Functional foods with added health benefits, such as anticancer effects, are currently of major interest to consumers. In the present study, SCH-P9 and SCH-P10 demonstrated antitumor effects and possessed apoptosis-inducing activities. $S$. constricta may therefore present a source of functional food, and its derivatives, SCH-P9 and SCH-P10, may be useful as anticancer therapies.
In conclusion, the results of the current study present the purification and characterization of two novel anticancer peptides derived from the peptide hydrolysates of S. constricta. The two peptides, SCH-P9 and SCH-P10, were identified as Leu-Pro-Gly-Pro (MW, 382.46 Da) and Asp-Tyr-Val-Pro (MW, 492.53 Da), respectively. SCH-P9 and SCH-P10 inhibited the growth of DU-145 and PC-3 cells in a dose- and time-dependent manner. These results indicate that $\mathrm{SCH}-\mathrm{P} 9$ and $\mathrm{SCH}-\mathrm{P} 10$ present a potential source of functional food, which may promote the emergence of tetrapeptides as novel functional food ingredients or antitumor drugs.

\section{Acknowledgements}

The present study was supported by the Natural Science Foundation of Zhejiang Province (grant nos. LY13C200004, LY15C200016, LY12C20005, LY12C20008, LQ16H300001, Y201534400 and 21136001315), the Science and Technology Department of Zhejiang Province (grant no. 2013C03036), the Scientific and Technologic Planning of Zhoushan (grant no. 2012C21013) and the Scientific Research Foundation of Zhejiang Ocean University (grant no. Q1408).

\section{References}

1. Chakrabarti S, Jahandideh F and Wu J: Food-derived bioactive peptides on inflammation and oxidative stress. Biomed Res Int 2014: 608979, 2014.

2. Mora L, Aristoy MC and Toldrá F: Bioactive Peptides in Foods. Encyclopedia Food Health: 395-400, 2016.

3. Udenigwe CC and Aluko RE: Food protein-derived bioactive peptides: Production, processing, and potential health benefits. J Food Sci 77: R11-R24, 2012.

4. Pan WR, Chen PW, Chen YL, Hsu HC, Lin CC and Chen WJ: Bovine lactoferricin $\mathrm{B}$ induces apoptosis of human gastric cancer cell line AGS by inhibition of autophagy at a late stage. J Dairy Sci 96: 7511-7520, 2013.

5. Wong MC, Goggins WB, Wang HH, Fung FD, Leung C, Wong SY, Ng CF and Sung JJ: Global Incidence and Mortality for Prostate Cancer: Analysis of Temporal Patterns and Trends in 36 Countries. Eur Urol 70: 862-874, 2016.

6. Siegel RL, Miller KD and Jemal A: Cancer Statistics, 2016. Ca Cancer J Clin 66: 7-30, 2016.

7. Cheng L, Wang C, Liu H, Wang F, Zheng L, Zhao J, Chu E and Lin X: A novel polypeptide extracted from Ciona savignyi induces apoptosis through a mitochondrial-mediated pathway in human colorectal carcinoma cells. Clin Colorectal Cancer 11: 207-214, 2012.

8. Huang TC, Lee JF and Chen JY: Pardaxin, an antimicrobial peptide, triggers caspase-dependent and ROS-mediated apoptosis in HT-1080 cells. Mar Drugs 9: 1995-2009, 2011.

9. Wang C, Liu M, Cheng L, Wei J, Wu N, Zheng L and Lin X: A novel polypeptide from Meretrix meretrix Linnaeus inhibits the growth of human lung adenocarcinoma. Exp Biol Med (Maywood) 237: 442-450, 2012.

10. Lyu P, Zhang SD, Yuen HF, McCrudden CM, Wen Q, Chan KW and Kwok HF: Identification of TWIST-interacting genes in prostate cancer. Sci China Life Sci 60: 386-396, 2017.

11. Chen W, Zheng R, Zhang S, Zhao P, Zeng H and Zou X: Report of cancer incidence and mortality in China, 2010. Ann Transl Med 2: 61, 2014.

12. Luesch H, Moore RE, Paul VJ, Mooberry SL and Corbett TH: Isolation of dolastatin 10 from the marine cyanobacterium Symploca species VP642 and total stereochemistry and biological evaluation of its analogue symplostatin 1. J Nat Prod 64: 907-910, 2001.

13. Damiani RM, Moura DJ, Viau CM, Caceres RA, Henriques JA and Saffi J: Pathways of cardiac toxicity: comparison between chemotherapeutic drugs doxorubicin and mitoxantrone. Arch Toxicol 90: 2063-2076, 2016. 
14. Mader JS, Richardson A, Salsman J, Top D, de Antueno R, Duncan R and Hoskin DW: Bovine lactoferricin causes apoptosis in Jurkat T-leukemia cells by sequential permeabilization of the cell membrane and targeting of mitochondria. Exp Cell Res 313: 2634-2650, 2007.

15. Okumura K, Itoh A, Isogai E, Hirose K, Hosokawa Y, Abiko Y, Shibata T, Hirata M and Isogai H: C-terminal domain of human CAP18 antimicrobial peptide induces apoptosis in oral squamous cell carcinoma SAS-H1 cells. Cancer Lett 212: 185-194, 2004.

16. Saadi S, Saari N, Anwar F, Hamid AA and Mohd Ghazali H Recent advances in food biopeptides: Production, biological functionalities and therapeutic applications. Biotechnol Adv 33: 80-116, 2015

17. Zheng L, Lin X, Wu N, Liu M, Zheng Y, Sheng J, Ji X and Sun M: Targeting cellular apoptotic pathway with peptides from marine organisms. Biochim Biophys Acta 1836: 42-48, 2013.

18. Song R, Wei RB, Luo HY and Yang ZS: Isolation and identification of an antiproliferative peptide derived from heated products of peptic hydrolysates of half-fin anchovy (Setipinna taty). J Functional Foods 10: 104-111, 2014

19. Sato S, Ohta K, Kojima K, Kozeki, Ohmachi and Yoshida T: Isolation and characterization of two types of xyloglucanases from a phytopathogenic fungus, Verticillium dahliae. J App Glycoscience 9: 110-112, 2016.

20. Singh BP, Vij S and Hati S: Functional significance of bioactive peptides derived from soybean. Peptides 54: 171-179, 2014.

21. Kim EK, Kim YS, Hwang JW, Lee JS, Moon SH, Jeon BT and Park PJ: Purification and characterization of a novel anticancer peptide derived from Ruditapes philippinarum. Pro Bioch 48: 1086-1090, 2013.

22. Kim EK, Joung HJ, Kim YS, Hwang JW, Ahn CB, Jeon YJ, Moon SH and Park PJ: Purification of a novel anticancer peptide from enzymatic hydrolysate of Mytilus coruscus. J Microbiol Biotechnol 22: 1381-1387, 2012.
23. Ke-Han XU, Shen XR and Chen GH: Angiotensin I-converting enzyme (ACE) inhibitory activity of enzymatic hydrolysate from three-spot hippocampus. Sci Technol Food Industry 36: 96-99, 2015 (In Chinese)

24. Vermeirssen V, Jon JV and Verstraete: Fractionation of angiotensin I converting enzyme inhibitory activity from pea and whey protein in vitro gastrointestinal digests. J Sci Food Agr 85: 399-405, 2005

25. Zhu Z, Qiu N and Yi J: Production and characterization of angiotensin converting enzyme (ACE) inhibitory peptides from apricot (Prunus armeniaca L.) kernel protein hydrolysate. Eur Food Res Technol 231: 13-19, 2010.

26. Huang F, Yang Z, Yu D, Wang J, Li R and Ding G: Sepia ink oligopeptide induces apoptosis in prostate cancer cell lines via caspase-3 activation and elevation of $\mathrm{Bax} / \mathrm{Bcl}-2$ ratio. Mar Drugs 10: 2153-2165, 2012.

27. Song R, Wei RB, Luo HY and Yang ZS: Isolation and identification of an antiproliferative peptide derived from heated products of peptic hydrolysates of half-fin anchovy (Setipinna taty). J Func Foods 10: 104-111, 2014.

28. Jumeri and Kim SM: Antioxidant and anticancer activities of enzymatic hydrolysates of solitary tunicate (Styela clava). Food Sci Biotechnol 20: 1075, 2011.

29. Watts KR, Morinaka BI, Amagata T, Robinson SJ, Tenney K, Bray WM, Gassner NC, Lokey RS, Media J, Valeriote FA and Crews P: Biostructural features of additional jasplakinolide (jaspamide) analogues. J Nat Prod 74: 341-351, 2011.

30. Pettit GR, Kamano Y, Fujii Y, Herald CL, Inoue M, Brown P, Gust D, Kitahara K, Schmidt JM, Doubek DL and Michel C: Marine animal biosynthetic constituents for cancer chemotherapy. J Nat Prod 44: 482-485, 1981.

31. Jiménez-Colmenero F: Potential applications of multiple emulsions in the development of healthy and functional foods. Food Res Int 52: 64-74, 2013. 